\title{
Chapter 20 \\ The Case of Huaraz: First Climate \\ Lawsuit on Loss and Damage Against an Energy Company Before German Courts
}

\author{
Will Frank, Christoph Bals and Julia Grimm
}

\begin{abstract}
The civil law case brought forward in 2016 by the Peruvian Saúl Luciano Lliuya with the support of the NGO Germanwatch against the German energy company RWE is the first climate lawsuit in Germany. It addresses the question whether and how the biggest greenhouse-gas emitters, such as energy suppliers, may be held liable for losses and damages caused by climate change. Specifically, the plaintiff sued the company for a contribution to safety measures that help avoid the outburst of a glacial lagoon fuelled by glacial retreat linked to anthropogenic climate change. The requested support for necessary risk management measures at the lake to reduce the risk of flooding are commensurate with the causal contribution of the company's share in historical $\mathrm{CO}_{2}$ emissions, approximately $0.5 \%$. After having been rejected by a district court in November 2017, the Court of Appeals accepted the case and took it forward to the evidentiary phase. This decision marks the first time that a court acknowledged that a private company is in principal responsible for its share in causing climate damages. The lawsuit has raised the issue of responsibility of large energy companies, and other emitters of greenhouse gas emissions, for climate change in terms of liability for nuisance caused to private property. The acceptance of the case and its entering into the evidentiary phase has written legal history and
\end{abstract}

W. Frank · C. Bals · J. Grimm (凶)

Germanwatch e.V., Bonn, Germany

e-mail: grimm@germanwatch.org

(C) The Author(s) 2019

R. Mechler et al. (eds.), Loss and Damage from Climate Change, Climate Risk

Management, Policy and Governance, https://doi.org/10.1007/978-3-319-72026-5_20 
the case may act as a model for lawsuits in other countries. Comparable legal bases for similar cases exist in numerous countries around the world. The decision thus may have implications for the responsibility of great emitters all around the globe in terms of communicating the relevant litigation risks to shareholders and building adequate financial reserves.

Keywords Litigation $\cdot$ Civil law $\cdot$ Glacial lake outburst flooding $\cdot$ Causation Peru $\cdot$ Huaraz

\subsection{The Case of Huaraz and Its Civil Law Dimension}

Loss and Damage caused by climate change has a civil law dimension (see book chapter by Simlinger and Mayer 2018). The case of Saúl Luciano Lliuya brought forward in 2016 against the German energy utility RWE is the first climate lawsuit in Germany that addresses the question if greenhouse gas emitters, such as big energy suppliers, may be held liable proportionally for safety measures necessary to protect others against the dangers to life and property caused by the consequences of climate change, such as through the accelerated retreat of glaciers and rising water levels of glacial lagoons.

The plaintiff, Saúl Luciano Lliuya, who lives in the Andean city of Huaraz in Peru, owns a house just below Palcacocha Glacier Lake (see Fig. 20.1). Global warming has led to dangerous increases in the lake's volume. At any time, a glacial ice avalanche may cause a glacial lake outburst flood (GLOF) from the lake (Rivas et al. 2015). Saúl Luciano Lliuya's family and house along with large parts of the city of Huaraz are at risk of being hit by such a wave. There are precedents of GLOFs causing death and destruction in the region: since 1941 such disasters have killed more than 30,000 people in the Cordillera Blanca region (Carey 2005). To ensure protection from the hazard, water levels of the glacier lake need to be reduced by upgrading the pumping system and strengthening the current protective moraine dam (see Fig. 20.2).

The intent of Saúl Luciano Lliuya's climate lawsuit, brought forward in 2016 against the German energy company RWE, is to get the company to make a contribution to safety measures at the lake in order to reduce the risk of flooding. This contribution is to be commensurate to the causal contribution of the company's share in historical $\mathrm{CO}_{2}$ emissions, approximately $0.5 \%$ (Heede 2014). As an affected landowner, Saúl Luciano Lliuya bases his claim against RWE on $\S 1004$ of the German Civil Code (BGB 2002), which reads as follows:

If the ownership is interfered with by means other than removal or retention of possession, the owner may require the disturber to remove the interference. If further interferences are to be feared, the owner may seek a prohibitory injunction. 

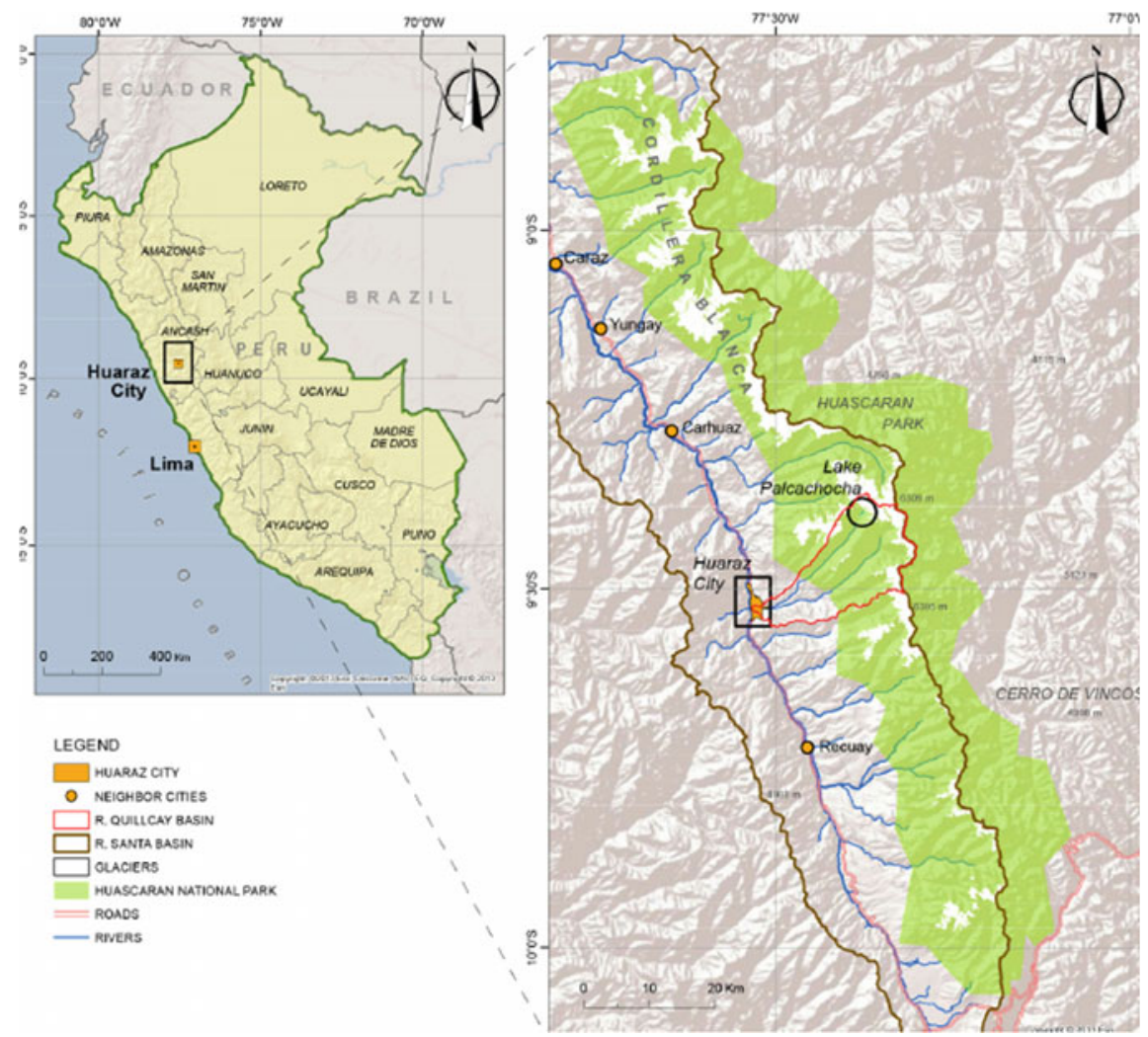

Fig. 20.1 Location of Lake Palcacocha and the city of Huaraz. Source Rivas et al. (2015)

\subsection{The Question of Causality}

For any claim based on $\S 1004$ BGB a legally relevant causal link has to be established between the respective activity of the defendant and the nuisance suffered by the plaintiff. The claim asserts that such a causal link can be established between $\mathrm{CO}_{2}$ emissions generated by the power plants operated by RWE and the imminent harm to the claimant's property. In German Civil Law the test for causality is the "conditio sine qua non" rule: Accordingly, causality is established if a certain consequence had not occurred fully or partially "but for" the said activity. Additionally, the principle of "adequacy" has to be fulfilled. Consequences which are so unlikely that their occurrence reasonably cannot be anticipated, are not imputed.

Causality in the Huaraz Case is strongly linked to scientific confidence as established e.g. by the assessments of the International Panel of Climate Change (IPCC 2013; Cramer et al. 2014). As shown in Fig. 20.3 of the IPCC Report of 2014, building on its detection and attribution framework (Cramer et al. 2014), the IPCC assigned high confidence that glacial retreat in South America is linked to anthropogenic climate change (item 1 in the figure; Magrin et al. 2014). 


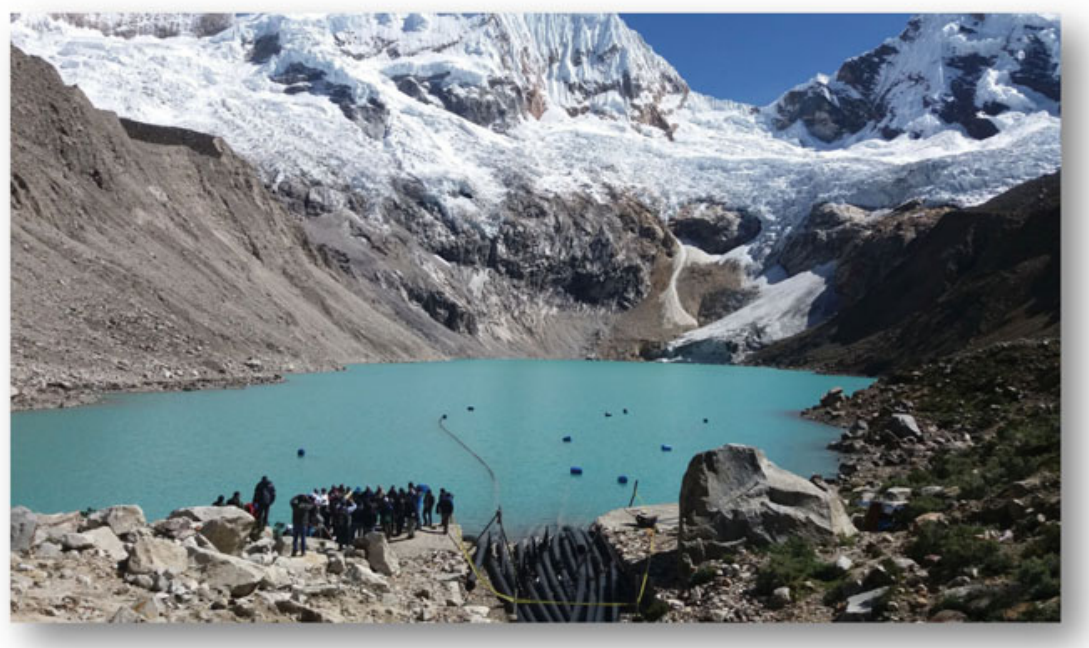

Fig. 20.2 Palcacocha Glacier Lake with the provisional pumping system in need of upgrading. Source Noah Walker-Crawford 2016

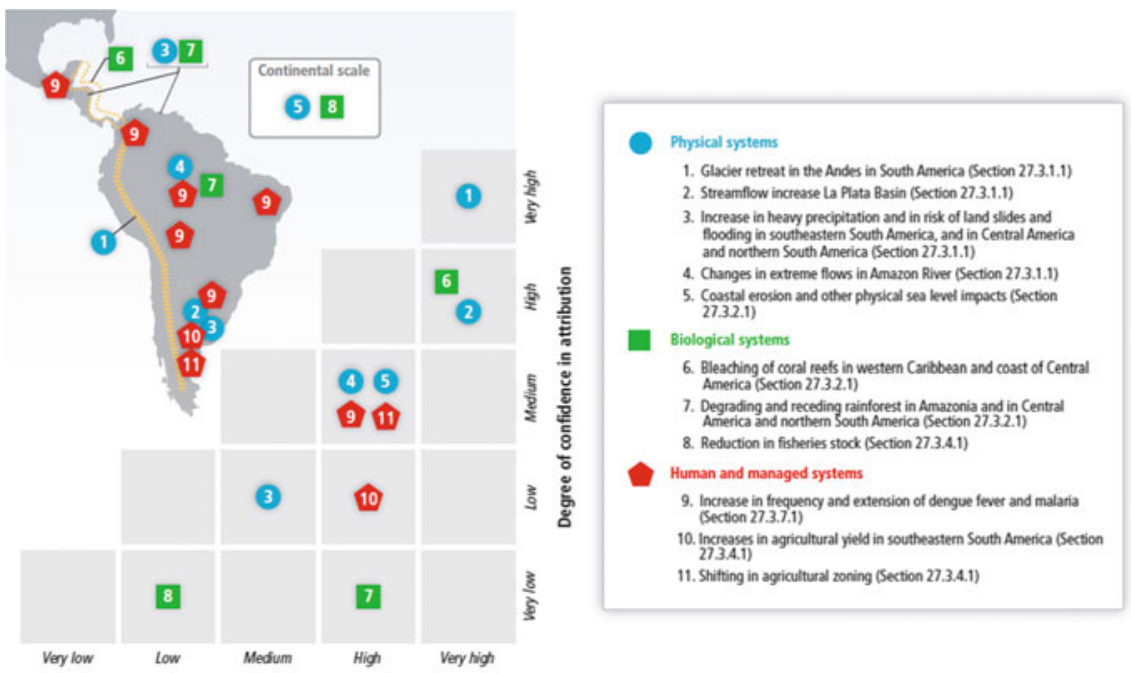

Degree of confidence in detection of a trend in climate-sensitive systems

Fig. 20.3 Detection and attribution for climate impacts in Central and South America. Source Magrin et al. (2014) (IPCC 5th assessment report) 


\subsection{The Ruling}

\section{The First-Instance Judgement}

In late 2016, the district court of Essen dismissed the case in the first instance denying the existence of legally-relevant causation between the greenhouse gas emissions by RWE and the endangerment of the claimant's property. Basically, the court argued that the processes of climate change and its consequences are so complex that it is virtually not possible to prove an individual causal link between $\mathrm{CO}_{2}$ emissions of single emitters and specific climate change impacts. The court further argued, with reference to the principle of "adequacy", that there are many contributors to the overall greenhouse gas burden in the atmosphere, and consequently the share of a single emitter is irrelevant for the specific climate change impacts caused.

\section{The Appeal}

In the appeal lodged with the next-higher instance, the Higer Regional Court of Hamm, North Rhine-Westphalia, the claimant asserted that the lower court misjudged the issues concerning causality. He argued that there is a scientifically provable causal chain between $\mathrm{CO}_{2}$ emissions from RWE's emissions and the increasing danger to the claimant's property being exposed to a possible outburst flood caused by a glacial ice avalanche. This causal chain can be established around four clearly definable steps: (1) A certain definable proportion of $\mathrm{CO}_{2}$ emissions from RWE power plants end up in the atmosphere. They contribute to higher concentrations of greenhouse gases in the entire atmosphere-irrespective of the origin of emissions-as described by physical laws (Cubasch et al. 2013); (2) Due to the increasing concentrations of greenhouse gases, radiative forcing in terms of the absorption of solar radiation increases, which correlates with an increase in average global temperature. In the Peruvian Andes, specifically, this has led to regional warming and no other reasons have been observed for the rise in average temperature (Magrin et al. 2014); (3) Increased temperature leads to accelerated glacial retreat and heavily increases the probability of glacial ice avalanches (Magrin et al. 2014); (4) Due to accelerated glacial melting the glacial lake's volume increases which consequently further raises the risk of harm to the claimant's property by an outburst flood caused by glacial ice avalanches. Additionally, the claimant-referring to the principle of adequacy, as used by the court, asserted that the contribution of RWE, the largest emitter in Europe to climate change, is not as low as not too carry weight. Accordingly, the claimant demanded a contribution from RWE to risk management measures at the lake commensurate with the company's contribution to global $\mathrm{CO}_{2}$ emissions. The claimant asserted that there is no legal reason why a large emitter, such as RWE, should be exempt from its climate-related legal responsibilities, and that a big emitter should not be treated like the numerous collectively irresponsible small emitters, whose individual contributions to climate warming are indeed not measurable. 


\section{The Decision to Accept the Case}

On November 13th 2017, the Higher Regional Court of Hamm in North RhineWestphalia accepted the case Lliuya against RWE. This decision marks the first time that a court acknowledged that a private company is in principal responsible for its share in causing climate damages. This applies if concrete damages or risks to private persons or their property can partly be assigned to the activities of the relevant company. On November 30th 2017, the case formally entered into the next stage-the taking of evidence. Now that the court accepted the legal argument of this case, the task for the plaintiff is to provide evidence for his claim before the court. The following questions play a central role and will need to be addressed in the hearing

- Is Saúl Luciano Lliuya's home in fact acutely endangered by a glacier outburst flood?

- Do RWE's historical emissions really amount to half a percent of global emissions since the beginning of industrialisation - and if not, to how much?

- Is there proof that these emissions contributed to accelerated glacier melting and the risk of flooding in Huaraz?

\subsection{The Outlook}

The lawsuit raises the issue of responsibility of large energy companies for climate change in terms of liability for nuisance and losses and damages. It may act as a model for similar lawsuits in other countries. The acceptance of the case and its entering in the evidentiary phase itself has already written legal history, says lawyer Roda Verheyen:

The OLG Hamm confirmed its vote of the oral hearing on November 13th 2017: Major emitters of greenhouse gases can be held liable for protective measures against climate damages. The decision establishes a solid argument for legally relevant causality in cases that were not accepted before, notably in reference to a negative ruling of the Federal Supreme Court on acid rain in 1987. Now we can prove in a concrete case that RWE contributed and continues to contribute to the risk of a local glacier outburst flood in Huaraz (Germanwatch 2017).

Beside the claimant's concrete concern about climate change impacts in Huaraz, the lawsuit, which is financially supported by the Foundation Zukunftsfähigkeit and technically supported by the NGO Germanwatch, qualifies as a legal test case. It addresses responsibility of energy suppliers with regard to bearing the social costs of using fossil fuels, costs which have been largely externalised. In addition to confirming the need for political solutions with regard to climate change induced Loss and Damage, the case has also shown to investors that they ought to consider the potential costs of legal liabilities in their energy investment decisions. These costs may fall on large emitters, effectively serving as a disincentive to continuing investing in fossil fuel-based energy production. 
Similar legal rules - from which climate responsibility of big greenhouse gas emitters may follow-exist in other countries around the world. The decision in the Huaraz Case will thus have implications for great emitters all around the globe in terms of them having to communicate the relevant litigation risks to shareholders and building adequate financial reserves. Investors will have to take those risks into account when taking investment decisions.

Of course, we do not consider it a long-term solution that the most vulnerable people around the world exposed to climate change related losses and damages have to file legal actions in order to defend their rights. Germanwatch thus emphasises the need for acting on responsibility and expects, as a consequence of litigation action, a strengthening of political will to protect affected people and hold big emitters accountable (Schäfer et al. 2018).

\section{References}

Bürgerliches Gesetzbuch [BGB] [Civil Code] (2002) Bundesgesetzblatt, Part I, 2002-01-08, No. 2, pp. 42-341, ISSN: 03411095

Carey M (2005) Living and dying with glaciers: people's historical vulnerability to avalanches and outburst floods in Peru. Global Planetary Change 47:122-134. https://doi.org/10.1016/j.gloplac ha.2004.10.007

Cramer W, Yohe G, Auffhammer M, Huggel C, Molau U, Da Silva Dias MAF, Solow A, Stone D, Tibig L (2014) Detection and attribution of observed impacts. In: Field CB et al (eds) Climate change 2014: impacts, adaptation, and vulnerability. Contribution of working group II to the fifth assessment report of the intergovernmental panel on climate change, Chap 18. Cambridge University Press, Cambridge, UK, and New York, NY, USA, pp 979-1037

Cubasch U, Wuebbles D, Chen D, Facchini MC, Frame D, Mahowald N, Winther JG (2013) Introduction. In: Stocker TF, Qin D, Plattner GK, Tignor M, Allen SK, Boschung J, Nauels A, Xia Y, Bex V, Midgley PM (eds) Climate change 2013: the physical science basis. Contribution of working group I to the fifth assessment report of the intergovernmental panel on climate change. Cambridge University Press, Cambridge, United Kingdom and New York, NY, USA, pp 119-158

Germanwatch (2017) Historic breakthrough with global impact in "climate lawsuit." Germanwatch. https://germanwatch.org/en/14795. Accessed 28 Jan 2018

Heede R (2014) Tracing anthropogenic carbon dioxide and methane emissions to fossil fuel and cement producers, 1854-2010. Clim Change 122(1-2):229-241

IPCC (2013) Climate change 2013: the physical science basis. In: Stocker TF, Qin D, Plattner G-K, Tignor M, Allen SK, Boschung J, Nauels A, Xia Y, Bex V, Midgley PM (eds) Contribution of working group I to the fifth assessment report of the intergovern-mental panel on climate change. Cambridge University Press, Cambridge, United Kingdom and New York, NY, USA, 1535 pp

James RA, Jones RG, Boyd E, Young HR, Otto FEL, Huggel C, Fuglestvedt JS (2018) Attribution: how is it relevant for loss and damage policy and practice? In: Mechler R, Bouwer L, Schinko T, Surminski S, Linnerooth-Bayer J (eds) Loss and damage from climate change. Concepts, methods and policy options. Springer, Cham, pp 113-154

Magrin G, Marengo J, Boulanger J-P, Buckeridge M, Castellanos E, Poveda E, Scarano F, Vicuña S (2014) Central and South America. In: Climate change 2014: impacts, adaptation, and vulnerability. Part B: regional aspects. In: Barros VR et al (eds) Contribution of working group II to the fifth assessment report of the intergovernmental panel on climate change. Cambridge University Press, Cambridge, United Kingdom and New York, NY, USA, pp 1499-1566 
Rivas DS, Somos-Valenzuela MA, Hodges BR, McKinney DC (2015) Predicting outflow induced by moraine failure in glacial lakes: the Lake Palcacocha case from an uncertainty perspective. Nat Hazards Earth Sys Sci 15:1163-1179. https://doi.org/10.5194/nhess-15-1163-2015

Schäfer L, Künzel V, Bals C (2018) The significance of climate litigation for the political debate on Loss\&Damage. Germanwatch Bonn

Schinko T, Mechler R, Hochrainer-Stigler S (2018) The risk and policy space for loss and damage: integrating notions of distributive and compensatory justice with comprehensive climate risk management. In: Mechler R, Bouwer L, Schinko T, Surminski S, Linnerooth-Bayer J (eds) Loss and damage from climate change. Concepts, methods and policy options. Springer, Cham, pp $83-110$

Simlinger F, Mayer B (2018) Legal responses to climate change induced loss and damage. In: Mechler R, Bouwer L, Schinko T, Surminski S, Linnerooth-Bayer J (eds) Loss and damage from climate change. Concepts, methods and policy options. Springer, Cham, pp 179-203

Open Access This chapter is licensed under the terms of the Creative Commons Attribution 4.0 International License (http://creativecommons.org/licenses/by/4.0/), which permits use, sharing, adaptation, distribution and reproduction in any medium or format, as long as you give appropriate credit to the original author(s) and the source, provide a link to the Creative Commons license and indicate if changes were made.

The images or other third party material in this chapter are included in the chapter's Creative Commons license, unless indicated otherwise in a credit line to the material. If material is not included in the chapter's Creative Commons license and your intended use is not permitted by statutory regulation or exceeds the permitted use, you will need to obtain permission directly from the copyright holder. 